\title{
PENGEMBANGAN MEDIA PEMBELAJARAN KOMIK MATEMATIKA SISWA KELAS IV SEKOLAH DASAR BERBASIS BUDAYA
}

\author{
Mila Kurniawarsih ${ }^{1}$, Indra Martha Rusmana ${ }^{2}$ \\ ${ }^{1,2}$ Universitas Indraprasta PGRI, Jakarta \\ millakurniawarsih@gmail.com ${ }^{1}$, indramartharusmana@ymail.com²
}

\begin{abstract}
The purpose of this study is to develop comic learning media as a learning medium for students in grade IV attractive elementary schools, so that student are not easily bored and bored when studying. This learning media is made based on an analysis of the needs of mathematical competencies that should be owned by grade IV elementary school students. Data collection tool in the form of a questionnaire for teachers and students. This study refers to the ADDIE development model. This research consists of several steps, namely: Analysis-Design-Development-iImplementation-Evaluation. Form this development produced a product in the form of mathematical comics as a learning medium. The product developed has passed the validation stage by experts and has been declared suitable for use in learning.
\end{abstract}

Keywords: Learning Media, Mathematics, Learning Media For Math Comics.

\begin{abstract}
Abstrak
Tujuan penelitian ini adalah mengembangkan media pembelajaran komik sebagai media pembelajaran untuk siswa kelas IV Sekolah Dasar yang menarik, sehingga siswa tidak mudah bosan dan jenuh ketika belajar. Media pembelajaran ini dibuat berdasarkan analisis kebutuhan terhadap kompetensi matematika yang seharusnya dimiliki oleh siswa Sekolah Dasar kelas IV. Alat pengumpul data berupa angket untuk guru dan siswa. Penelitian ini mengacu pada Model pengembangan ADDIE. Penelitian ini terdiri dari beberapa langkah, yaitu: Analysis-Design-Develepoment-Implementation-Evaluation. Dari pengembangan ini dihasilkan produk berupa komik matematika sebagai media pembelajaran. Produk yang dikembangkan sudah melaui tahap validasi oleh para ahli dan dinyatakan layak untuk digunakan dalam pembelajaran.
\end{abstract}

Kata kunci: Media Pembelajaran, Matematika, Media Pembelajaran Komik Matematika.

Received: December 20, 2019 / Accepted: April 25, 2020 / Published Online: April 30, 2020 
Jurnal Lebesgue : Jurnal Ilmiah Pendidikan Matematika, Matematika dan Statistika

Mila Kurniawarsih, Indra Martha Rusmana

Volume 1, No. 1, April 2020 hal.39-48

\section{PENDAHULUAN}

Matematika merupakan salah satu mata pelajaran yang diajarkan pada setiap jenjang pendidikan formal. Matematika memegang peranan penting dalam kehidupan sehari-hari maupun dalam menghadapi kemajuan IPTEK sehingga matematika perlu dibekalkan kepada setiap peserta didik sejak SD, bahkan sejak TK (Hudojo, 2003:40)

Mengingat pentingnya peranan matematika maka pembelajaran matematika setiap sekolah perlu mendapatkan perhatian yang serius. Oleh karena itu, para siswa dituntut untuk menguasai pelajaran matematika, karena disamping sebagai ilmu dasar juga sebagai sarana berfikir ilmiah yang sangat berpengaruh untuk menunjang keberhasilan belajar siswa dalam menempuh pendidikan yang lebih tinggi dan diupayakan penguasaan materi kepada peserta didik yang dianggap masih rendah.

Dalam mencapai keberhasilan pembelajaran guru tidak hanya menggunakan satu metode pembelajaran saja, tetapi juga guru dituntut untuk menggunakan metode yang bervariasi. Metode yang bervariasipun harus sesuai dengan tuntutan dan harapan dari kompetensi dasar pada setiap mata pelajaran, sehingga metode yang dipilih guru harus benar-benar membantu siswa dalam pembelajarannya. Namun demikian, kenyataan yang dijumpai di kelas terkadang tidak sesuai dengan yang diharapkan. Walaupun guru telah menggunakan metode pembelajaran yang bervariasi, hasilnya jauh dari apa yang diharapkan guru.

Hal ini di alami oleh guru SD ketika mengajar di kelas IV pada mata pelajaran matematika. Guru telah menggunakan metode ceramah,demontrasi, dan tanya jawab, namum hasilnya masih kurang sesuai dengan yang diharapkan. Ternyata dari 20 siswa, tidak ada siswa yang mendapat nilai 70 ke atas.

Guru merupakan komponen dalam penyelenggaraan sumber daya manusia. Kualitas guru yang professional berdampak terhadap kualitas lulusan yang dihasilkan dan juga berdampak pada yang lain. Guru sebagai pelaku utama proses pembelajaran dikelas merupakan potensi utama perkembangan pendidikan, sudah selayaknya guru setiap saat harus mengembangkan potensinya dalam rangka meningkatkan kualitas pembelajaran. Bagitu banyak cara yang bisa ditempuh guru dalam rangka meningkatkan kualitas pembelajaran, salah satunya adalah pemanfaatan media pembelajaran. Media sebagai alat bantu mengajar, berkembang sedemikian pesatnya seseuai dengan kemajuan teknologi. Media mempunyai banyak jenis sehingga dapat dimanfaatkan seseuai materi yang akan disampaikan. Dalam pembelajaran matematika banyak guru yang mengeluhkan rendahnya kemampuan siswa dalam menyelesaikan soal matematika. Memang matematika memiliki karakteristik yang abstrak sehingga bagi yang ingin mempelajarinya merasa kesulitan. Hal ini menjadi tantangan tersendiri bagi guru agar menjadikan matematika dianggap mudah oleh siswa.

Seperti yang dikemukakan oleh Hasbullah (2014:15) bahwa media pembelajaran matematika adalah sarana dalam menyajikan, mempelajari, memahami dan mempermudah dalam mempelajari matematika karena matematika bersifat abstrak, bagi siswa SD dan SMP berfikir secara abstrak mungkin merupakan hal yang sangat sulit. Maka dari itu, sangat diperlukan sebuah alat peraga atau 
Jurnal Lebesgue : Jurnal Ilmiah Pendidikan Matematika, Matematika dan Statistika

Mila Kurniawarsih, Indra Martha Rusmana

Volume 1, No. 1, April 2020 hal.39-48

sebuah media, karena akan sangat membantu siswa dalam mempelajari hal yang abstrak melalui benda konkret. Karena media merupakan alat bantu guru dalam menyampaikan materi dalam proses belajar mengajar dan mempermudah siswa untuk memahami materi yang sudah disampaikan.

Salah satu media yang mampu membangkitkan minat dan motivasi siswa dalam belajar matematika terutama pada anak SD adalah komik. Komik adalah karya sastra berbentuk cerita yang disajikan bergambar, yang didalamnya terdapat satu tokoh yang diunggulkan. Cerita didalam komik umumnya adalah cerita fiksi, seperti halnya karya sastra lainnya. Komik bukan hanya sekedar cerita bergambar yang bersifat menghibur seperti pandangan orang pada umumnya, tetapi komik mempunyai makna lebih dari itu, yaitu komik merupakan bentuk komunikasi visual yang memiliki kekuatan untuk menyampaikan informasi secara populer dan mudah dimengerti (Maharsi, 2011).

Nilai edukatif media komik dalam proses pembelajaran tidak diragukan lagi. Menurut Wahyuningsih (2012: 20) menyatakan media komik dalam proses pembelajaran menciptakan minat para siswa, mengefektifkan proses pembelajaran, dapat meningkatkan minat belajar dan menimbulkan minat apresiasinya. Tidak hanya itu banyak sekali manfaat media komik dalm pembelajaran diantaranya yaitu memicu sensor motoric diusia dini, mengenal lebih banyak warna, bisa berimajinasi untuk menyampaikan pendapatnya sendiri. Media komik berisikan konseptual matematika yang mengacu kepada kehidupan sehari-hari siswa sebagai penggunaan konsep matematika lebih mudah dipahami siswa apalagi ditambah dengan komik yang berisikan gambar-gambar dapat membantu pembelajaran matematika.

Matematika merupakan bahan pelajaran yang kurang disenangi oleh siswa, dikarenakan penjelasan yang ada disetiap buku kurang disenangi siswa yang saat ini lebih tertarik dengan media yang bersifat visual dan berwarna. Oleh karena itu, peneliti tertarik untuk mengembangkan metode pembelajaran matematika dengan menggunakan komik.

Pemilihan pengembangan media komik ini merupakan salah satu cara untuk meningkatkan motivasi belajar siswa. Karena salah satu cara untuk meningkatkan motivasi belajar yaitu degan memberikan fasilitas belajar yang baik. Salah satu fasilitas yang dapat disediakan yaitu media pembelajaran komik. Penggunaan media komik berbasis budaya ini diharapkan dapat membangkitkan keinginan dan minat baru pada siswa karena tidak jarang siswa lebih tertarik untuk membaca komik daripada membaca buku pelajaran.

Pengembangan komik sebagai media pembelajaran diharapkan dapat mempermudah siswa untuk memahami pembelajaran matematika, mengurangi kejenuhan siswa pada media pembelajaran matematika yang kurang variatif dan mendukung siswa untuk belajar secara mandiri. Suatu media yang baik harus memenuhi berbagai persyaratan baik dari segi penampilan, isi, kemudahan dalam penggunaannya serta mampu membuat siswa menjadi lebih mudah dalam memahami konsep materi dan memiliki motivasi yang lebih dalam belajar. Maka, dalam pengembangan media pembelajaran komik ini memilih Mata Pelajaran Matematika kelas IV SD pada materi Semester II untuk dipelajari siswa secara lebih mendalam. 
Jurnal Lebesgue : Jurnal Ilmiah Pendidikan Matematika, Matematika dan Statistika

Mila Kurniawarsih, Indra Martha Rusmana

Volume 1, No. 1, April 2020 hal.39-48

Media pembelajaran komik khususnya pada Mata Pelajaran Matematika dapat menjadikan kegiatan pembelajaran lebih menarik dan menyenangkan serta dapat mempermudah siswa dalam memahami Mata Pelajaran Matematika sehingga siswa termotivasi untuk belajar baik di dalam kelas maupun secara mandiri.

\section{METODE PENELITIAN}

Tujuan penelitian yang akan dilakukan adalah untuk mengetahui seberapa efektifitasnya Media Pembelajaran Komik Matematika Siswa Kelas IV Berbasis Budaya Pada Materi Semester II yang dibuat peneliti.

Penelitian yang akan digunakan adalah merupakan jenis penelitian pengembangan atau research and development yang berorentasi pada pengembangan dan mengimplementasikan produk yang dihasilkan. Produk yang dikembangkan adalah bahan instruksional pada pembelajaran matematika sekolah dasar kelas IV untuk memfasilitasi siswa dalam pemecahan masalah matematika khususnya pada materi semester II.

Memurut Sugiyono (2015:297) Metode penelitian dan pengembangan (R\&D) adalah metode penelitian yang digunakan untuk menghasilkan produk tertentu dengan menggunakan fasilitas penelitian yang bersifat analisis kebutuhan dan untuk menguji keefektifan produk tersebut supaya dapat berfungsi di masyarakat luas.

Penelitian dan pengembangan model ini secara garis besar dapat dirangkum menjadi tiga tahapan, yaitu: studi pendahuluan, pengembangan model, dan validasi model. Model yang disusun dalam penelitian ini ialah pengembangan model pembelajaran yang diharapkan dapat digunakan oleh berbagai kalangan. Analisis kebutuhan adalah mengumpulkan informasi secara empirik dan teoretis dapat dikategorikan sebagai studi pendahuluan. Membuat perencanaan atau desain model, mengembangkan desain model, melakukan uji coba model tahap I, revisi atau penyempurnaan model yang dikembangkan, uji coba model tahap II, dan revisi atau penyempurnaan model yang dikembangkan dapat dikategorikan sebagai pengembangan model. Kemudian implementasi produk hasil pengembangan, revisi dan finalisasi, serta desiminasi dan implementasi hasil dapat dikategorikan sebagai validasi model.

\section{HASIL PENELITIAN DAN PEMBAHASAN}

\section{Hasil}


Jurnal Lebesgue : Jurnal Ilmiah Pendidikan Matematika, Matematika dan Statistika

Mila Kurniawarsih, Indra Martha Rusmana

Volume 1, No. 1, April 2020 hal.39-48

Paparan deskriptif hasil penelitian siswa terhadap pengembangan media pembelajaran komik berbasis budaya ini menggunakan metode kuesioner dengan instrumen angket yang akan disajikan seperti di bawah ini.

Tabel 1. Hasil Tanggapan Siswa (Aspek Tampilan)

\section{$\begin{array}{llllll}\text { No. Aspek yang dinilai } & \sum x & \sum x_{1} & \% & \text { Kriteria }\end{array}$}

\begin{tabular}{llllll}
\hline 1 & Ketepatan pemilihan warna cover & 5 & 5 & 100 & Valid \\
\hline 2 & Kemenarikan pemilihan cover & 5 & 5 & 100 & Valid \\
\hline 3 & Kejelasan gambar & 5 & 5 & 100 & Valid \\
\hline 4 & Kejelasan warna gambar & 4 & 5 & 80 & Valid \\
\hline 5 & Gambar dalam komik menarik & 5 & 5 & 100 & Valid \\
\hline 6 & Gambar nyata sesuai dengan konsepnya & 5 & 5 & 100 & Valid \\
\hline 7 & Jenis dan ukuran huruf mudah dibaca & 5 & 5 & 100 & Cukup Valid \\
\hline 8 & Ukuran komik tepat & 4 & 5 & 80 & Valid \\
\hline Jumlah & $\mathbf{3 8}$ & $\mathbf{4 0}$ & $\mathbf{9 5}$ & Valid \\
\hline
\end{tabular}

Tabel 2. Hasil Tanggapan Siswa (Aspek Isi/Materi)
No. Aspek yang dinilai
$\sum x \quad \sum x_{1} \quad \%$
Kriteria

\begin{tabular}{llllll}
\hline 1 & Kejelasan Materi & 5 & 5 & 100 & Valid \\
\hline 2 & Materi sesuai dengan kebutuhan siswa & 5 & 5 & 100 & Valid \\
\hline 3 & Gambar memperjelas materi & 5 & 5 & 100 & Valid \\
\hline $\begin{array}{l}\text { Materi disajikan secara sederhana dan } \\
\text { jelas }\end{array}$ & 5 & 5 & 100 & Valid \\
\hline 5 & Materi disajikan secara runtut & 5 & 5 & 100 & Valid \\
\hline Jumlah & $\mathbf{2 5}$ & $\mathbf{2 5}$ & $\mathbf{1 0 0}$ & Valid \\
\hline
\end{tabular}




\section{Tabel 3. Hasil Tanggapan Siswa (Aspek Pembelajaran)}

No. Aspek yang dinilai

$$
\sum x \quad \sum x_{1} \quad \%
$$

Kriteria

\begin{tabular}{llllll}
\hline 1 & Kejelasan petunjuk belajar & 5 & 5 & 100 & Valid \\
\hline 2 & $\begin{array}{l}\text { Ketersediaan dan kejelasan petunjuk } \\
\text { jawaban latihan }\end{array}$ & 5 & 5 & 100 & Valid \\
\hline 3 & Kejelasan petunjuk mengerjakan soal & 4 & 5 & 80 & Valid \\
\hline 4 & Kesesuaian soal dengan materi & 5 & 5 & 100 & Valid \\
\hline 5 & Materi mudah dipelajari & 5 & 5 & 100 & Valid \\
\hline 6 & $\begin{array}{l}\text { Memahami materi ini bermanfaat dalam } \\
\text { pembelajaran }\end{array}$ & 5 & 5 & 100 & Valid \\
\hline 7 & Kemudahan memilih sumber belajar & 4 & 5 & 80 & Valid \\
\hline 8 & $\begin{array}{l}\text { Bahan ajar komik matematika } \\
\text { mempermudah mempelajari materi } \\
\text { matematika }\end{array}$ & 5 & 5 & 100 & Valid \\
\hline 9 & $\begin{array}{l}\text { Bahan ajar mempermudah belajar secara } \\
\text { mandiri }\end{array}$ & 5 & 5 & 100 & Valid \\
\hline 10 & $\begin{array}{l}\text { Bahan ajar pembelajaran membuat belajar } \\
\text { menjadi lebih menyenangkan }\end{array}$ & 5 & 5 & 100 & Valid \\
\hline Jumlah & $\mathbf{4 8}$ & $\mathbf{5 0}$ & $\mathbf{9 6}$ & Valid \\
\hline
\end{tabular}

Tabel 4. Hasil Tanggapan Siswa (Aspek Keterbacaan)

$\begin{array}{llllll}\text { No. } & \text { Aspek yang dinilai } & \sum x & \sum x_{1} & \% & \text { Kriteria }\end{array}$

\begin{tabular}{llllll}
\hline 1. & Tulisan terbaca dengan jelas & 5 & 5 & 100 & Valid \\
\hline 2. & $\begin{array}{l}\text { Bahasa yang digunakan lugas dan } \\
\text { mudah dipahami }\end{array}$ & 5 & 5 & 100 & Valid \\
\hline 3. & $\begin{array}{l}\text { Bahasa yang digunakan sudah } \\
\text { komunikatif }\end{array}$ & 5 & 5 & 100 & Valid \\
\hline 4. & $\begin{array}{l}\text { Kalimat yang dipakai sederhana dan } \\
\text { langsung ke sasaran }\end{array}$ & 5 & 5 & 100 & Valid \\
\hline 5. & $\begin{array}{l}\text { Kalimat yang dipakai mewakili isi pesan } \\
\text { atau informasi yang ingin disampaikan }\end{array}$ & 4 & 5 & 80 & Valid \\
\hline Jumlah & & $\mathbf{2 4}$ & $\mathbf{2 5}$ & $\mathbf{9 6}$ & Valid \\
\hline
\end{tabular}

Keterangan :

$\sum x$ : jumlah jawaban penilai

$\sum x_{\mathbf{1}}$ : jumlah jawaban tertinggi

$\%$ : prosentase nilai kevalidan

Sedangkan pendapat dan saran dari siswa terhadap bahan ajar komik matematika berbasis budaya ini sebagai berikut : 
Tabel 5. Saran Siswa

\section{Pendapat dan Saran Hasil Revisi}

Komik ini sangat menyenangkan untuk belajar, Tulisan Sudah diperbaiki tulisannya agak kekecilan.

Berdasarkan hasil dari tabel pendapat dan saran siswa yang telah disajikan, maka diketahui bahwa media pembelajaran sudah layak dengan beberapa revisi pada bagian-bagian yang perlu diperbaiki. Terutama memperbanyak materi pada media pembelajaran komik matematika berbasis budaya tersebut.

Namun, secara umum jika dilihat dari tabel sebelumnya dimana pada aspek tampilan pada komik dengan hasil validasi 95\%, pada aspek isi/materi pada komik dengan hasil validasi 100\%, pada aspek pembelajaran pada komik dengan hasil validasi 96\%, pada aspek keterbacaan pada komik dengan hasil validasi 96\%. Maka media pembelajaran komik berbasis budaya pada materi semester II sudah baik dan layak digunakan sebagai media pembelajaran di kelas.

\section{Pembahasan}

Media pembelajaran yang diadopsi dari model pengembangan ADDIE diharapkan mampu memfasilitasi pencapaian kompetensi-kompetensi siswa kelas IV SD dalam pemecahan masalah matematis. Pemecahan tujuan pembelajaran secara utuh tidak hanya mencangkup transfer ilmu antara guru dan siswa, melainkan ditekankan pada proses awal penyusunan pembelajaran itu sendiri.

Dalam sebuah produk sudah pasti memiliki kelebihan dan kekurangan, termasuk media pembelajaran yang peneliti kembangkan. Adapun kelebihan media pembelajaran ini seperti tokoh komik menggunakan tokoh wayang orang (bagong, gareng, petruk dan semar) dibuat lucu dan menarik, full color, dan menggunakan bahasa yang mudah dipahami siswa kelas IV SD. Selain dicetak dalam bentuk komik, peneliti juga membuat digital dalam bentuk jpg, untuk memudahkan siswa untuk membaca dan menghemat biaya percetakan. Selain kelebihan di atas, media pembelajaran ini juga memiliki beberapa kekurangan, seperti biaya percetakan yang cukup mahal, akses yang terbatas untuk melihat media pembelajaran yang peneliti kembangkan, hingga belum terbiasanya siswa menggunakan komik sebagai media pembelajaran sehingga perlu adanya bimbingan.

Media komik yang peneliti kembangkan masih harus diuji kelayakan secara terus menerus, karena uji yang dilakukan peneliti hanya uji terbatas dan hanya melibatkan beberapa ahli, yakni ahli materi, ahli bahasa dan ahli pengembangan. Produk yang peneliti kembangkan masih jarang ditemukan dalam proses pembelajaran matematika di sekolah, karena pada umumnya sekolah menggunakan metode konvensional, oleh karena itu peneliti mengembangkan media komik matematika untuk menjadikan media tambahan dalam pembelajaran matematika di sekolah, terutama untuk siswa kelas IV Sekolah Dasar. 
Jurnal Lebesgue : Jurnal Ilmiah Pendidikan Matematika, Matematika dan Statistika

Mila Kurniawarsih, Indra Martha Rusmana

Volume 1, No. 1, April 2020 hal.39-48

Hasil ujicoba yang telah dilakukan selanjutnya digunakan untuk melihat kevalidan, keparktisan, dan keefektifan media pembelajaran berbasis komik yang telah dikembangkan. Model yang dipilih oleh peneliti adalah pengembangan ADDIE yaitu diawali dari tahap analisis, desain, pengembangan, implementasi dan evaluasi.

\section{Analisis}

Analisis dilakukan untuk mendapatkan gambaran kondisi awal siswa,guru dan media yang digunakan. Dari hasil observasi telah dijelaskan bahwa siswa banyak yang kurang peduli terhadap proses pembelajaran karena terbatasnya media yang digunakan dalam proses pembelajaran. Maka dari hasil analisis awal, peneliti berinisiatif untuk mengembangkan sebuah media. Media yang dipilih adalah media pembelajaran berbasis komik. Hal ini dimaksudkan agar dapat mengubah kebiasaan siswa yang kurang peduli terhadap pembelajaran menjadi peduli dan tertarik dengan proses pembelajaran. Menurut Ali Muhson (2010:4) mengatakan bahwa salah satu manfaat media pembelajaran adalah dapat membangkitkan ,motivasi, sehingga dapat memperbesar perhatian individual siswa untuk seluruh anggota kelompok belajar sebab jalannya pelajaran tidak membosankan dan tidak monoton

\section{Desain}

Tahap desain adalah tahap dimana peneliti merancang media yang akan dikembangkan. Pada tahap desain ini peneliti merancang media pembelajaran berbasis komik. Peneliti membuat komik dengan memasukkan karakter Punakawan sebagai tokoh. Hal ini dimaksudkan agar siswa lebih mudah dan tertarik untuk memahami materi yang ada di dalam media pembelajaran berbasis komik. Sampul komik didesain dirancang semenarik mungkin agar sejak pertama siswa melihat sampul komik tersebut mereka langsung bersemangat untuk membuka dan membacanya.

\section{Pengembangan}

Pada tahap pengembangan perangkat media pembelajaran berbasis komik yang telah selesai dibawa ke ahli media, materi dan bahasa untuk diperiksa. Adapun masukan para ahli untuk komik sendiri yaitu cover diperbaiki, teks disesuaikan warnanya, kejelasan teks,tidak menggunakan kalimat rancu, rubah kalimat tidak efektif menjadi kalimat efektif, pengunaan tanda baca, tampilkan SK/KD, dan buat tes formatif di setiap SK/KD. Masukan ini diberikan dengan alasan untuk lebih memperjelas isi komik maupun tampilan komik. Berdasarkan hasil pengamatan dan uraian teori di atas, maka media pembelajaran komik yang dikembangkan memenuhi kategori valid, karena aspek-aspek dari komik yang dikembangkan menunjukkan nilai rata-rata yang valid. Di hasil validasi materi ada beberapa kriteria yang cukup valid karena kurangnya kejelasan petunjuk belajar, pemberian latihan, pemberian tes formatif dan ketersedian kunci jawaban. Sedangkan validasi ahli pengembangan kriteria seluruhnya valid. Validasi ahli Bahasa juga ada beberapa kriteria yang cukup valid karena kurang tepat pemilihan Bahasa dalam menguraikan materi, kalimat yang dipakai kurang sederhana dan kurang konsistensi dalam 
Jurnal Lebesgue : Jurnal Ilmiah Pendidikan Matematika, Matematika dan Statistika

Mila Kurniawarsih, Indra Martha Rusmana

Volume 1, No. 1, April 2020 hal.39-48

penggunaan istilah. Karena semua aspek penilaian berada pada kategori valid maka media pembelajaran berbasis komik dapat digunakan pada pengembangan selanjutnya, yaitu uji coba lapangan pada pembelajaran di kelas, untuk kemudian diukur kepraktisan dan keefektifannya. Namun demikian, berdasarkan catatan yang diberikan para ahli pada setiap komponen yang divalidasi, perlu dilakukan perbaikan-perbaikan kecil atau seperlunya sesuai dengan catatan yang diberikan.

\section{Implementasi}

Tahap implementasi adalah tahap di mana media telah diuji cobakan di dalam kelas. Pada tahap ini media pembelajaran komik dibagikan kepada siswa dan digunakan sebagai media pembelajaran.

\section{Evaluasi}

Evaluasi adalah tahap di mana peneliti memberikan butir-butir tes kepada siswa untuk mengukur keefektifan produk yang dibuat, dapat dilihat dari tes hasil belajar siswa. Hal inipun sejalan dengan yang dikemukakan oleh Trianto (2009:20) bahwa suatu pembelajaran dikatakan efektif apabila memenuhi persyartan utama yaitu ketepatan antara kandungan materi ajar denga kemampuan siswa.

\section{KESIMPULAN}

Media pembelajaran matematika berbentuk komik untuk SDN kelas IV semester II ini telah dikembangkan menggunakan model ADDIE yang dikembangkan oleh Dick and Carry, yang meliputi tahap Analysis (Analisis), Design (perancangan), Development (Pengembangan), Implementation (implementasi), dan Evaluation (Evaluasi). Pada tahap analisis terdapat analisis awal dan akhir yang dilakukan dengan survei pendahuluan untuk dapat mengidentifikasi permasalahan dan kebutuhan media pembelajaran, kemudian dilakukan analisis tugas dan konsep serta spesifikasi tujuan pembelajaran yang ingin dicapai.

Pada tahap berikutnya yaitu tahap perancangan, media pembelajaran komik matematika mulai didesain dengan langkah menyusun tes instrumen, media serta memilih format yang sesuai untuk selanjutnya dibuat rancangan awal yang kemudian akan divalidasi untuk mendapatkan penilaian mengenai kualitas dan kelayakan produk yang dikembangkan.

Pada tahap pengembangan ini, rancangan awal yang divalidasi dan direvisi oleh ahli di bidangnya meliputi ahli materi, ahli media pembelajaran, dan ahli bahasa untuk kemudian dilakukan uji pengembangan dan uji coba kepada siswa.

Setelah melalui tahap validasi dan revisi oleh ahli didapat hasil bahwa media pembelajaran komik matematika menarik dan layak digunakan dengan kualifikasi sangat baik. Hal tersebut didapatkan dari hasil dari penilaian ahli materi dengan hasil validasi $77 \%$ dan pada aspek isi dengan hasil $90 \%$, penilaian ahli pengembangan 94,67\%, dan penilaian ahli bahasa 73,33\%. Kemudian hasil tanggapan siswa dimana pada aspek tampilan pada komik dengan hasil validasi 95\%, pada aspek 
Jurnal Lebesgue : Jurnal Ilmiah Pendidikan Matematika, Matematika dan Statistika

Mila Kurniawarsih, Indra Martha Rusmana

Volume 1, No. 1, April 2020 hal.39-48

isi/materi pada komik dengan hasil validasi $100 \%$, pada aspek pembelajaran pada komik dengan hasil validasi 96\%, pada aspek keterbacaan pada komik dengan hasil validasi 96\%. Dengan hasil penilaian ini menunjukkan bahwa media komik matematika ini layak untuk digunakan pada pembelajaran matematika kelas IV SD semester II.

\section{DAFTAR PUSTAKA}

Herman, Hudojo. 2003. Pengembangan Kurikulum dan Pembelajaran Matematika. Malang: FMIPA Universitas Negeri Malang.

Hasbullah. 2014. Media Pembelajaran Matematika. Jakarta: Savitra Collage.

Maharsi, Indira. 2011. Komik : Dunia Kreatif Tanpa Batas. Yogyakarta: KATA BUKU.

Wahyuningsih, Ary Nur. 2012. Pengembangan Media Komik Bergambar Materi Sistem Saraf Untuk pembelajaran yang Menggunakan Strategi PQ4R. Journal Of Innovative Science Education. Vol. 1 (1), 19-27 (ISSN. 2252-6412).

Sugiyono. 2015. Metode Penelitian Kuantitatif Kualitatif dan R \& D. Bandung: Alfabeta. Muhson, A. 2010. Pengembangan Media Pembelajaran Berbasis Teknologi Informasi. Jurnal Pendidikan Akutansi Indonesia, 8(2).

Trianto. 2009. Mendesain Pembelajaran Inovatif-Progresif: Konsep, Landasan dan Implementasi pada KTSP. Jakarta: Prenada Media Group. 